\title{
THE MAIN CHARACTERISTICS OF SPATIAL THINKING IN HIGH-SCHOOL GEOGRAPHY TEXTBOOK QUESTIONS AND TASKS IN THE REPUBLIC OF SRPSKA (B\&H)
}

\author{
DOI: https://doi.org/10.18509/GBP210565t
}

UDC: $373.5 .091 .39: 911(497.6)$

\author{
Mlađen Trifunović \\ Aleksandra Petrašević \\ University of Banja Luka, Faculty of Natural Sciences and Mathematics, Banja Luka \\ (Republic of Srpska), Bosnia and Herzegovina
}

\begin{abstract}
Spatial thinking remains one of the basic cognitive competencies of modern education and STEM disciplines in particular, regardless of the fact how the great body of work defines it. Geography courses at all levels of education represent a fertile ground for encouraging spatial thinking, which has been insufficiently capitalized on for different reasons. In order to support spatial thinking in geography classes, the authors believe that it is crucial to undertake an initial analysis of its characteristics focusing on school textbooks. It is the textbooks, including tasks and questions set before students, which represent a "gauge" of advantageous students' cognitive abilities and skills. The paper investigates the characteristics of spatial thinking in high-school geography textbook questions and tasks used in the Republic of Srpska (B\&H).

The research was conducted on the basis of the methodology used by Trifunović (2020), which is basically an extended methodology developed by Jo (2007) and Jo \& Bernardz (2009). Trifunović's methodology introduces 2 important new elements into the research of spatial thinking - conceptions of spatiality (topological conceptions based on Aristotle's teaching on topos and absolute conceptions of spatiality) and spatial metaphors. The research analyzed 1437 questions and tasks from the textbook.
\end{abstract}

Keywords: spatial thinking, geography textbook questions and tasks, spatial conception, spatial metaphors, interpretation.

\section{INTRODUCTION}

Ever since 1980s, there has been a "spatial turn" in the humanities and social sciences. Spatiality has come a long way from a sort of an inert scene of social events to one of the key factors of conducting and understanding social processes. On the other hand, the rapid processes of globalization and urbanization, the development of information society, and the general introduction of technology into the lives of people demand special cognitive abilities referring to spatial thinking [1], [2], [3].

The US National Research Council Report [4] underlines the fact that both scientists and educators should pay careful and systematic attention to spatial thinking in order to encourage both practical and theoretical spatial thinking among students. It is clear that geography, both as a science and a school subject, has a potential to inspire higher cognitive abilities and skills as it has been indicated by earlier studies [5], [6].

Gersmehl $[6,99]$ claims that one of the most pertinent findings of previous studies is the transfer taking place within spatial cognition. The relevance of studying spatial thinking and its application in teaching geography is pointed out by the Lucerne Declaration on 
Geographical Education for Sustainable Development which pronounces the necessity to comprehend basic spatial concepts as key ideas which help students understand the world as a meaningful unit [7].

Consequently, it is crucial to provide a clear answer to a seemingly easy question regarding the definition of spatial thinking. A great body of work [8], [9], [10], [11], [12], [13], [14], [15], [16], [6], [17], [18], [19], [20] offers different definitions by different authors, both formally and substantially. From a formal and vocabulary point of view, there are different terms used to refer to spatial thinking, such as spatial literacy, spatial ability, spatial intelligence and geographical reasoning. Substantially, most definitions use three basic elements as follows: concepts of space, different tools for space representation, and operational combinations of these activities in the process of reasoning [4, 12]. Kastens and Ishikawa [16] suggest a broader definition by materializing the process of reasoning through categories of interpretation and prediction, also introducing spatial metaphors. It is evident that most attempts to define spatial thinking focus on listing relevant concepts. From the geographical point of view, it is understandable that each element within a system must be, in some way, a part of a whole. The previous definition is missing this principle. The definition also fails to elaborate on different meanings of specific concepts of spatiality. Concepts may obtain different meanings, as can be observed in cases of location or boundary concepts, which might be comprehended from geometrical, cultural or ontological aspects. Hence, conception of spatiality represents a basic structure or an organization matrix of spatial thinking, its demonstration and representation. We can think of conception as a spatial code, the function of which matches the so-called final interpreter [21].

A plausible definition of spatial thinking should also contain a connective structure which would "provide" concepts with specific meanings by materializing them. The authors believe that it is the conception of spatiality what the definition is lacking [19], [20]. Our definition of spatial thinking is as follows: Spatial thinking is a complex cognitive activity composed of five interconnected elements - conception of spatiality (1), concepts of spatiality (2) space representation (3) process interpretation (4) and the usage of spatial metaphors in non-spatial thinking (5) [20].

It is the school textbooks that clearly indicate a state of a science in a specific society. As sources of knowledge, these textbooks reflect the existing scientific truths presented in the text materials. On the other hand, their didactic and methodical elements reflect the didactic and methodical side of the teaching process. According to Vučenov [22], a textbook is both a source of knowledge and a medium of knowledge transfer.

In order to develop spatial cognitive skills within the teaching process, it is necessary to analyze to which extent the textbooks and their methodical and didactic aspects actually stimulate these skills. Earlier studies of textbooks focusing on characteristics of spatial thinking [23], [17], [24], [25], [20] represent initial steps which may serve as guidelines for designing future geography textbooks.

\section{MATERIALS AND METHODS}

We believe that parts of the textbooks referring to tasks and questions are places where structural components of spatial thinking are easiest to detect and where encouragement of spatial thinking among students is most pronounced.

The research consisted of extracting all questions and tasks from high school geography textbooks, and doing an analysis of their content with regard to certain elements of spatial thinking. This analysis was performed on the basis of the methodology used by Trifunović 
[20], which is basically an extended methodology developed by Jo [23] and Jo \& Bernardz [17]. Trifunović's methodology in the research of spatial thinking, in accordance with his definition of spatial thinking, introduces 2 important new elements - spatial metaphors and conceptions of spatiality. Along with the absolute conception of space, this methodology also entails Aristotle's topological conception [26], [27], [20] which author believe to be the essence of the systems approach in geography.

Following the mentioned methodology, questions and tasks are analyzed through the six categories:

1. The location of questions (in the text, as an appendix, end of a lesson) 2. The type of conception of spatiality (absolute or topological) 3. The type of spatial concept (nonspatial, primitive, simple, complex) 4 . The type of interpretation demanded of students in tasks and questions (reproduction, interpretation of relations, projection of processes) 5. Do the questions and tasks demand specific graphical representations? 6. Are the students asked to use spatial metaphors in non-spatial thinking?

The next methodological step was to encode the element of spatial thinking in the questions which enabled the analysis. For instance, the textbook question Name some scientific disciplines in geography is coded as V-7, G-1, D-2, F-1, G-0, H-1, I-5. Once we decode the sequence, it means the following: V-7 - The question is on page 7 in the analyzed textbook; G-1 - The question is located in the text; D-2 - It is the absolute conception of spatiality; F-1 - The question used a non-spatial concept; G-0 - The students are not requested to use the spatial relation representation; $\mathrm{H}-1$ - An answer to the question require the reproduction of facts; I-5 - The students are not requested to use spatial metaphors.

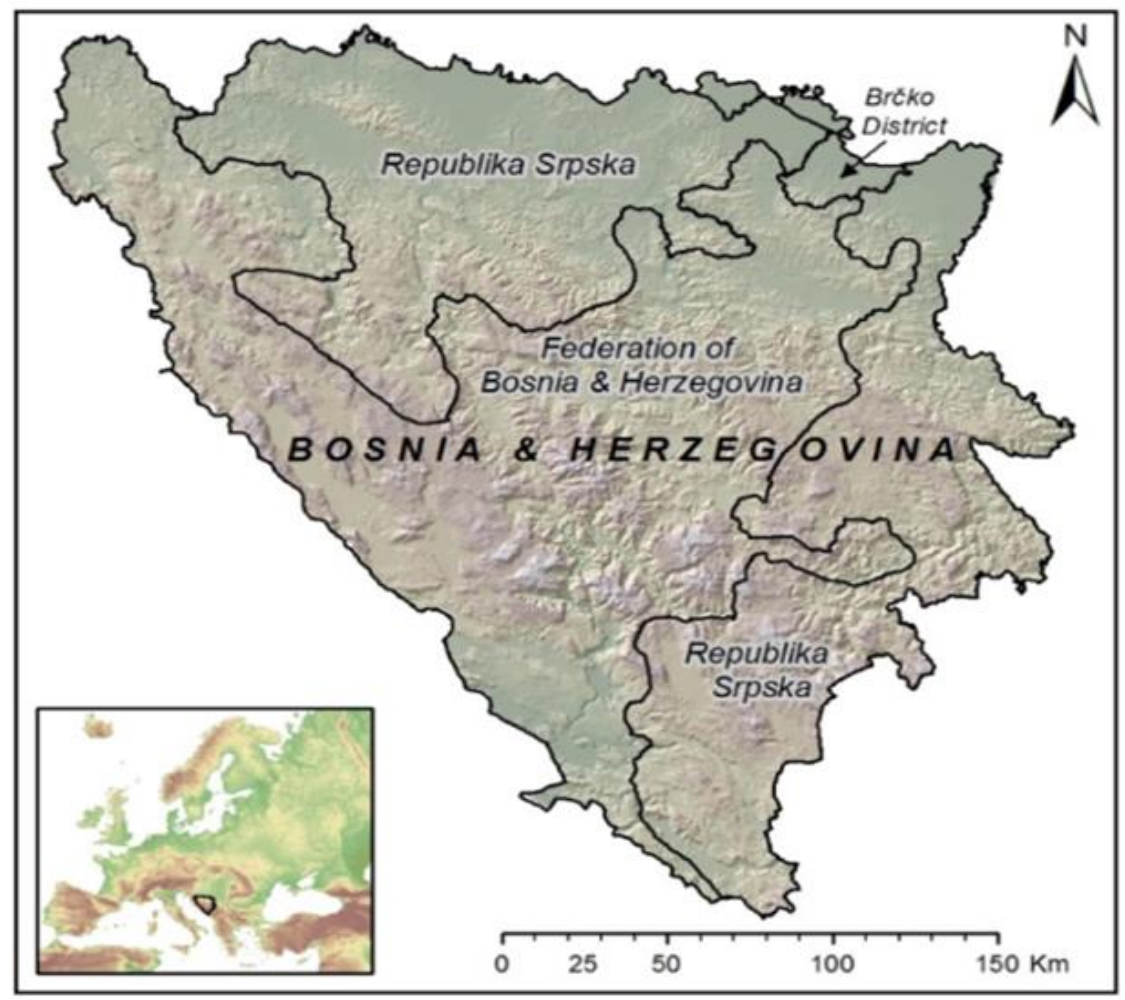

Figure 1. Geographical position of Republic of Srpska. Source: [28]

The research was conducted in the territory of Republika Srpska (B\&H) (Figure 1.), where we analyzed the following five high-school geography textbooks: the 1 st grade 
textbook for vocational high-school students, the 2 nd grade textbook for Grammar School students, the 3 rd grade textbook for Grammar School students, the 1 st grade textbook for economy-business-trade high-school students, and the 1 st grade (3-year high-school) and 2 nd grade (4-year high-school) textbook for students attending the vocational high-school of tourism and catering. For practical reasons, the textbooks are labeled as A, B, C, D, and E, respectively.I

\section{RESULTS}

The analytical technique used for the analysis of tasks and questions in the high-school textbooks comprised, as mentioned in the introduction, the following categories conception of spatiality, concepts of spatiality, interpretation, graphical representation, the usage of metaphors, and the location of tasks and questions in the textbooks. All these categories represent a gauge helping us analyze aspects of spatial thinking and their interconnection, which is the primary objective of the study. There are 1437 tasks and questions analyzed in five textbooks.

\section{CONCEPTIONS OF SPATIALITY}

Results of the analysis of tasks and questions in high-school textbooks in the Republic of Srpska indicate that, within the category of conception of spatiality, there are $425(29.6 \%)$ tasks and questions in the subcategory of topological conception of spatiality and 1012 (70.4\%) tasks and questions in the subcategory of absolute conception of spatiality [20].

Table 1. Conception of spatiality in different textbooks

\begin{tabular}{|l|l|l|l|l|l|l|l|l|l|l|}
\hline & \multicolumn{2}{|l|}{ Textbook A } & \multicolumn{2}{l|}{ Textbooks B } & \multicolumn{2}{l|}{ Textbook C } & \multicolumn{2}{l|}{ Textbook D } & \multicolumn{2}{l|}{ Textbook E } \\
\hline & $\mathrm{n}$ & $\%$ & $\mathrm{n}$ & $\%$ & $\mathrm{n}$ & $\%$ & $\mathrm{n}$ & $\%$ & $\mathrm{n}$ & $\%$ \\
\hline Topological & 64 & 26.4 & 74 & 25.3 & 113 & 42.5 & 111 & 31,4 & 63 & 22.2 \\
\hline Absolute & 178 & 73.6 & 218 & 74.7 & 153 & 57.5 & 242 & 68.6 & 221 & 77.8 \\
\hline Total & 242 & 100 & 292 & 100 & 266 & 100 & 353 & 100 & 284 & 100 \\
\hline
\end{tabular}

There is also a significant disparity among conceptions of spatiality emerging during the analysis of different geographical materials, i.e. during different approaches to the analysis of geographical materials. There are two approaches in geographical studies, methodology design, and geography teaching organization at all levels - regional and thematic. The reason for these two approaches is purely didactic but it often results in simplification and schematization of the teaching content and methods. The thematic approach is commonly used for the introduction of geography as a science and it focuses on the structure and spatial distribution of a specific geographical component. The distribution is usually illustrated via maps displaying the Earth structure, layers, genesis, relief, etc. The purpose of this approach is to set foundation for the more complex regional approach, i.e. a synthetic approach to processing geographical content. Geography teaching is based on the pyramid model where the base covers the studying of natural geographical components, which will later on be used in the synthesis of socialgeographical segments within a specific regional unit.

Given these two approaches, the analysis of textbooks indicates that the textbook A, which addresses 1st graders, represents a paradigm of the thematic approach, whereas the textbook B adopts the regional approach as it addresses the regional geographical units in line with the 3rd grade Grammar School curriculum. 
Table 2. The distribution of conceptions of spatiality in line with approaches to the teaching content

\begin{tabular}{|l|l|l|l|l|}
\hline & \multicolumn{2}{l|}{ Textbooks } \\
\hline & \multicolumn{2}{l|}{ Thematic A } & \multicolumn{2}{l|}{ Regional B } \\
\hline Conceptions & $\mathrm{N}$ & $\%$ & $\mathrm{~N}$ & $\%$ \\
\hline Topological & 64 & 26.4 & 113 & 42.5 \\
\hline Absolute & 178 & 73.6 & 153 & 57.5 \\
\hline Total & 244 & 100 & 266 & 100 \\
\hline
\end{tabular}

Table 2 clearly shows that the topological conception of spatiality prevails in the textbook $\mathrm{B}$, meaning that the tasks and questions formulated within the regional approach encourage the interpretation of mutual connections among the elements of the environment. It is in this textbook that the topological conception covers $113(42.5 \%)$ tasks and questions.

The absolute conception of spatiality is more pronounced in the 1st grade textbook with the total of $178(73.6 \%)$ tasks and questions. These findings indicate that there is a correlation between the systems approach and the absolute conception, i.e. between the regional approach and the topological conception of spatiality.

\section{CONCEPTS OF SPATIALITY}

The concepts are distributed within the absolute conception as follows: there are $58.5 \%$ (592/1012) of non-spatial concepts, one third (331/1012) are primitive concepts, $3.7 \%$ are complex concepts, and 5.1\% (52/1012) are simple concepts of spatiality in the analyzed tasks and questions (Table 3).

On the other hand, the topological conception of spatiality displays an opposite trend. Complex concepts are most pronounced and they are detected in 292 tasks out of 425 tasks which include topological conception in total. Tasks with non-spatial concepts are the fewest with only 12 instances $(2.8 \%)$.

Table 3. The total ratio between the concepts and conceptions of spatiality

\begin{tabular}{|l|l|l|l|l|}
\hline & \multicolumn{3}{l|}{ Conceptions } \\
\hline & \multicolumn{2}{l|}{ Topological } & \multicolumn{2}{l|}{ Absolute } \\
\hline Concepts & $\mathrm{n}$ & $\%$ & $\mathrm{~N}$ & $\%$ \\
\hline Non-spatial & 12 & 2.8 & 592 & 58.5 \\
\hline Primitive & 32 & 7.5 & 331 & 32.7 \\
\hline Simple & 89 & 21 & 52 & 5.1 \\
\hline Complex & 292 & 68.7 & 37 & 3.7 \\
\hline Total & 425 & 100 & 1012 & 100 \\
\hline
\end{tabular}

There are $7.5 \%(32 / 425)$ primitive concepts of spatiality and 21\% (89/425) simple concepts in the total number of tasks including topological conception.

Table 4. The distribution of concepts of spatiality in line with the task location

\begin{tabular}{|l|l|l|l|l|l|l|}
\hline & \multicolumn{2}{l}{ In the text } & \multicolumn{2}{l|}{ As an appendix } & \multicolumn{2}{l|}{ End of a lesson } \\
\hline & $\mathrm{n}$ & $\%$ & $\mathrm{n}$ & $\%$ & $\mathrm{n}$ & $\%$ \\
\hline Non-spatial & 85 & 30.9 & 6 & 10.3 & 513 & 46.5 \\
\hline Primitive & 98 & 35.6 & 17 & 29.3 & 248 & 22.5 \\
\hline Simple & 25 & 9.1 & 8 & 13.8 & 108 & 9.8 \\
\hline Complex & 67 & 24.4 & 27 & 46.6 & 235 & 21.2 \\
\hline Total & 275 & $100 \%$ & 58 & $100 \%$ & 1104 & $100 \%$ \\
\hline
\end{tabular}


Most tasks and questions in the analyzed textbooks are located in the end of a lesson (1104) in cases of all four categories of the concepts of spatiality. Still, most tasks and questions located in the end of a lesson belong to non-spatial concepts (513/1104) (Table 4).

Primitive concepts of spatiality are detected in 248 tasks and questions located in the end of a lesson, whereas simple concepts of spatiality are found in each tenth task and question (108/1104).

\section{TYPES OF INTERPRETATION}

Results indicate that most tasks and questions demand that the students reproduce facts. There are 788 tasks in this category, i.e. $54.8 \%$ of total tasks and questions. We may infer that this is an unfavorable indicator because the students are encouraged to use only the lowest level of cognition - to memorize information and repeat them without any analytic and synthetic expansion of knowledge. The tasks that require the highest level of cognition (projection of processes) are the fewest (26/1437). Percentually, the highschool geography textbooks include only $1.8 \%$ of such tasks and questions.

Table 5 systematically lists the types of interpretation requested in each textbook. The textbook $\mathrm{B}$ mostly covers tasks and questions which require the memorization and reproduction of specific facts and data (percentually) and there are $58.9 \%$ of reproductive tasks in this textbook. Speaking of this category, the absolute values are most pronounced in the textbook D - 201 tasks out of the total number.

The textbook B also includes the fewest tasks and questions which are cognitively least challenging. It is only in this textbook that the percentage of such tasks is less than 50 percent $-48.5 \%$.

Tasks and questions which primarily focus on the interpretation of processes are also most frequent in the textbook $C(133 / 266)$. In this category, the percentage of such tasks and questions is $45.5 \%$ in the textbook $\mathrm{A}$ and $39.1 \%$ in the textbook $\mathrm{D}$. In other two textbooks, such tasks share similar percentage - $43 \%$ in the textbook E and $41.1 \%$ in textbook B.

Table 5. The distribution of types of interpretation for each textbook

\begin{tabular}{|c|c|c|c|c|c|c|c|c|c|c|}
\hline \multirow{3}{*}{ Types of interpretation } & \multicolumn{10}{|c|}{ Textbooks } \\
\hline & \multicolumn{2}{|l|}{$\mathbf{A}$} & \multicolumn{2}{|l|}{$\mathbf{B}$} & \multicolumn{2}{|l|}{$\mathbf{C}$} & \multicolumn{2}{|l|}{ D } & \multicolumn{2}{|l|}{$\mathbf{E}$} \\
\hline & $\mathrm{n}$ & $\%$ & $\mathrm{n}$ & $\%$ & $\mathrm{n}$ & $\%$ & $\mathrm{n}$ & $\%$ & $\mathrm{n}$ & $\%$ \\
\hline Reproduction of facts & 126 & $\begin{array}{l}52 . \\
1\end{array}$ & 172 & 58.9 & 129 & 48.5 & 201 & 56.9 & 160 & $\begin{array}{l}56 . \\
4\end{array}$ \\
\hline $\begin{array}{ll}\text { Interpretation } & \text { of } \\
\text { processes } & \end{array}$ & 110 & $\begin{array}{l}45 . \\
5\end{array}$ & 120 & 41.1 & 133 & 50 & 138 & 39.1 & 122 & 43 \\
\hline Projection of processes & 6 & 2.4 & 0 & 0 & 4 & 1.5 & 14 & 4 & 2 & 0.6 \\
\hline Total & 242 & 100 & 292 & 100 & 266 & 100 & 353 & 100 & 284 & 100 \\
\hline
\end{tabular}

Speaking of tasks and questions which demand the projection of processes as a high level cognitive activity, it is the textbook D that includes most of these in both absolute and percentage values -14 tasks and questions (4\%). Secondly, there is the textbook A with six such tasks $(2.4 \%)$. We should point out that the textbook B does not include any of such tasks and questions. The fewest tasks which demand the projection of processes are found in the textbook $\mathrm{E}(0.6 \%)$. 


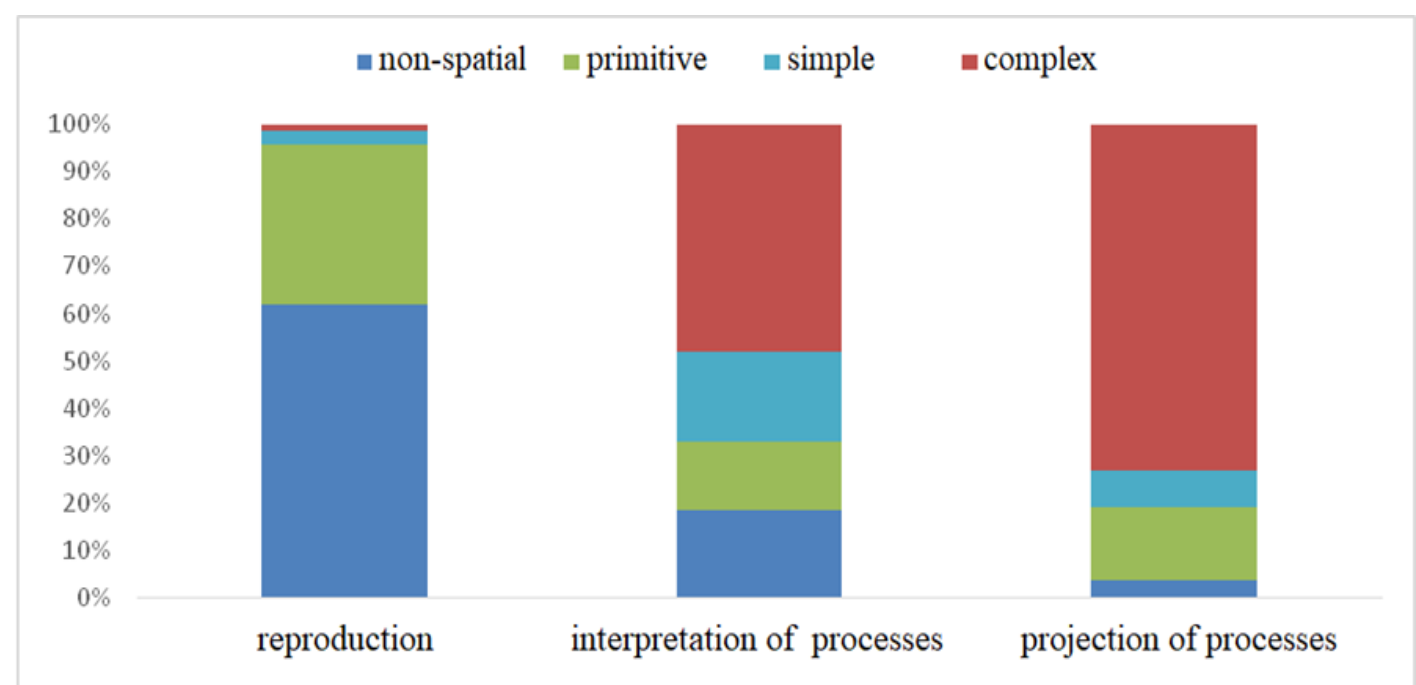

Figure 1. The required types of question interpretation in line with the concepts of spatiality in total

Figure 1 demonstrates the ratio between the required types of interpretation and the used concepts of spatiality. There is an evident connection linking higher concepts and cognitively more challenging functions. Among tasks and questions which require reproduction of specific facts, there are most non-spatial (61.9\%) and primitive (34\%) concepts. On the other hand, tasks and questions requiring the projection of different geographical processes are dominated by complex concepts of spatiality $(73.1 \%)$, with only $3.8 \%$ of non-spatial concepts.

\section{GRAPHICAL REPRESENTATION AND THE USAGE OF METAPHORS}

Table 6 outlines tasks and questions which require graphical representation, either as a basic or an additional element, for each textbook indivially. A general feature of this category is a remarkably small number of such tasks - only 24 out of 1437 . Given the fact that the ability to graphically represent spatial relations is one of key components of spatial thinking as many authors point out [29], [30], [6], [31] such approach essentially constricts the ability to encourage spatial thinking in high-school geography classes. The required graphical representations usually refer to plotting geographical locations or areas with some dominant agricultural crops in maps without any representations of relations among spatial phenomena, objects or processes.

Table 6. Number of tasks which require the graphical representation per textbook and total

\begin{tabular}{|l|l|l|l|l|l|l|}
\hline & Textbook A & Textbook B & Textbook C & Textbook D & Textbook E & Total \\
\hline Number & 3 & 9 & 3 & 8 & 1 & 24 \\
\hline $\begin{array}{l}\text { Percentage of } \\
\text { graphical tasks }\end{array}$ & 12.5 & 37.5 & 12.5 & 33.3 & 4.2 & 100 \\
\hline $\begin{array}{l}\text { Percentage } \\
\text { in total }\end{array}$ & 1.2 & 3.1 & 1.1 & 2.3 & 0.4 & 1.7 \\
\hline
\end{tabular}

Spatial metaphors, the role of which is to transfer spatial cognition within a field where it is not required, are rarely singled out in high-school geography textbooks in the Republic of Srpska. Spatial metaphors are detected in only $0.3 \%$ of analyzed tasks and questions [20]. 


\section{DISCUSSION}

Our findings prove the predominance of the quantitative spatial analysis paradigm in our geography textbooks. Students are generally asked to determine locations of geographical objects, either by finding or plotting them on a map, which we refer to as positional reference. On the other hand, this paradigm is evident in tasks including arithmetic operations for calculating different absolute and percentage indicators, which we refer to as quantitative reference.

Topological conception is present in less than one third of tasks and questions in the target textbooks. Given the fact that these textbooks are used in high-schools, this finding is unsatisfactory. Although we believe that the aforementioned paradigm and the tasks within it are valuable, it is still crucial to insist on tasks and questions focusing on the analysis of functional and hierarchical relations among spatial objects and phenomena. The reason for this is the pertinence of encouraging students' higher cognitive activities necessary for everyday life. Furthermore, the analysis of PISA tests unveils that the test tasks within the field of geoscience require (geo)topological perception of relations among specific phenomena.

Strictly speaking, concepts of spatiality encompass only the last three groups (primitive, simple, complex). It was for the purpose of analysis that non-spatial concepts were included despite the conceptual inconsistency. The validity of such decision lies in the fact that it is now possible to compare data with the "real" concepts of spatiality. It is the non-spatial concepts that prevail in the analyzed tasks and questions $-42 \%$ of all concepts. The obtained results suggest that it is necessary to reconceptualize the highschool textbooks by increasing the occurrence of "real" concepts of spatiality in tasks and questions and decreasing "non-spatial" concepts which refer to facts and reproduction.

According to our findings, reproduction covers almost 55\% of all tasks and questions. Interpretation is required in $43.4 \%$ and evaluation and projection in only $1.8 \%$ of all tasks and questions.

Since the analyzed textbooks are used in high-schools, the reproduction should be minimized and more complex types of interpretation should be encouraged. Primarily, the tasks and questions should include graphical components and inspire so-called graphicasy [32], [33].

Last but not least, textbooks should inspire students to think metaphorically and develop an ability to apply their geographical thinking outside geography classes.

\section{REFERENCES}

[1] Wetzel, J. Early Spatial Reasoning Predicts Later Creativity and Innovation, Especially in STEM Fields. (2013, July 15). Retrieved January 10, 2018 from https://news.vanderbilt.edu/2013/07/15/early-spatial-reasoning-predicts-later-creativity-andinnovation/

[2] Dangermond, J. Spatial Thinking Is Fundamental. (2017, November 2). Retrieved January 18,2018 from https://www.forbes.com/sites/esri/2017/11/02/spatial-thinking-isfundamental/\#178412d77aab

[3] Трифуновић, M. Мјесто географског образовања у доба STEM дисциплина? Herald, RS (BiH), 22, pp 21-33, 2018. doi:10.7251/HER2218021T

[4] Council, N. R. Learning to think spatially: GIS as support system in K-12 curriculum. Washington, D.C.: The National Academies Press, USA, 2006.

[5] Leat, D. Thinking Through Geography. London, Chris Kington Publishing, 1998. 
[6] Gersmehl, P. Teaching Geography (2nd Edition), New York, Guilford, 2008.

[7] Марић,Ђ и Трифуновић,М. Практикум методике наставе географије, УНИБЛ, Природно-математички факултет, Бања Лука, РС (БиХ), 2014.

[8] Nystuen, J.D. Identification of some fundamental spatial concepts. Papers of the Michigan Academy of Science, Arts, Letters , USA, 48, pp 373-384, 1963.

[9] Beck, R. Spatial meaning and the properties of the environment, In Environmental Perception and Behavior Research. Paper no. 109, ed. D. Lowenthal, 18-29. Chicago: Department of Geography, University of Chicago.Cambridge, Harvard University Press, USA, pp 99-102, 1967.

[10] Papageorgiou, G. J. Description of a basis necessary to the analysis of spatial systems, Geographical Analysis 1(2), USA, pp 213-215, 1969.

[11] McGee, M. G. Human Spatial Abilities: Sources of sex differences, New York, Praeger, 1979.

[12] Lohman, D. F. Spatial ability: A review and reanalysis of the correlational literature (Tech. Rep. No. 8), Stanford, CA: Stanford University, Aptitude Research project, School of Education, USA, 1979.

[13] Howard Gradner. Frames of Mind. The Theory of Myltiple Intelligences, Basic Books, New York, 1983.

[14] Uttal, D. H. Seeing the big picture: Map use and the development of spatial cognition, Developmental Science, USA, 3, pp 247-86, 2000.

[15] Golledge, R. G. The nature of geographic knowledge, Annals of the Association of American Geographers, USA, 92 (1), pp, 1-14, 2002.

[16] Kastens, K. A., \& Ishikawa, T. Spatial Thinking in the Geosciences and Cognitive Sciences: A Cross-Disciplinary Look at the Intersection of the Two Fields, In C. A. Manduca \& D. Mogk (Eds.), Earth and Mind: How Geologists Think and Learn about the Earth, Geological Society of America, USA, pp. 51-74, 2006.

[17] Jo, Injeong \& Bednarz, Sarah. Textbook Questions to Support Spatial Thinking: Differences in Spatiality by Question Location. Journal of Geography, USA,110, pp 70-80, 2011.

[18] Unwin David J. Numbers aren't nasty: a workbook of spatial concepts, SPLINT, UK, London, 2010.

[19] Trifunović, M. Definition of Spatial Thinking. From Concepts to Conceptions, Herald, RS (BiH), 24, pp 77-89, $2020 \mathrm{https} / / /$ doi.org/10.7251/HER2024077T

[20] Трифуновић, М. Просторно мишљење у геонаукама - основне концепције, модели психокогнитивног развоја и методологија истраживања, Географско друштво Републике Српске, Бања Лука, РС (БиХ) 2020.

[21] Määttänen, P. Semiotics of Space: Peirce and Lefebvre. Semiotica, Germany, 166(1-4), pp 453-461, 2007.

[22] Вученов, Н. (1984): Место и улога уџбеника у процесу школске наставе и учења у зборнику радова Прилози теорији уџбеника, pp 5-39, Београд, ЗУНС, 1984.

[23] Jo, Injeong. Aspects of spatial thinking in geography textbook questions, Master's thesis, Texas A\&M University, 2007. Available electronically from http : / /hdl .handle .net /1969.1 /ETD -TAMU - 1516.

[24] Scholz, Michael \& Huynh, Niem \& Brysch, Carmen \& Scholz, Ruojing. An Evaluation of University World Geography Textbook Questions for Components of Spatial Thinking, Journal of Geography,USA, 113, pp 208-219, 2014. 
[25] Nguyen, Ngoc-Anh \& Muniz-Solari, Osvaldo \& Dang, Tien \& Nguyen, Thao. Reviewing Spatial Thinking in Geography Textbooks Questions from The Perspective of Spatial Thinking. IOP Conference Series: Earth and Environmental Science, USA, 338, 012042. 2019.

[26] Трифуновић, М. Аристотел у Крајини Појам краја у Аристотеловој филозофији простора, у Зборник радова поводом обиљежавања двадесетогодишњице рада друштва Републике Српске, Географско друштво Републике Српске, Бања Лука, РС (БиХ), pp. 413442, 2013.

[27] Трифуновић, М. Онтолошке и епистемолошке недоречености постсруктуралистичке парадигме у географији, Гласник - Herald, Географско друштво Републике Српске, Бања Лука, РС (БиХ), свеска 20, pp, 25-39, 2016.

[28] Radislav TOŠIĆ, Novica LOVRIĆ \& Slavoljub DRAGIĆEVIĆ . ASSESSMENT OF THE IMPACT OF DEPOPULATION ON SOIL EROSION: CASE STUDY - REPUBLIKA SRPSKA (BOSNIA AND HERZEGOVINA), Carpathian Journal of Earth and Environmental Sciences, Romania, Vol. 14, No. 2, p. 505 - 518, 2019

[29] Прокић, Б. (1984). Улога и достигнућа дидактичко-методичке компоненте наших уџбеника.У зборнику радова Прилози теорији уџбеника, ЗУНС, Београд, Србија, pp, 41-91, 1984.

[30] Levin, J. R., \& Mayer, R. E. Understanding illustrations in text. In B. K. Britton, A. Woodward, and M. Binkley (Eds.), Learning from Textbooks: Theory and Practice, Hillsdale, NJ, USA, pp. 95-119, 1993.

[31] Lee, Jongwon \& Bednarz, Robert. (2012). Components of Spatial Thinking: Evidence from a Spatial Thinking Ability Test. Journal of Geography,USA, 111. pp, 15-26, 2012.

[32] Balchin, W.G. Graphicacy. American Cartographer, USA, 3 (1), 1976.

[33] Aldrich, F. K. \& L. Sheppard. Graphicacy: the fourth 'R'?, Primary Science Review, USA, 64, pp, $8-11,2000$. 